medRxiv preprint doi: https://doi.org/10.1101/2021.09.01.21262957; this version posted September 7, 2021. The copyright holder for this preprint (which was not certified by peer review) is the author/funder, who has granted medRxiv a license to display the preprint in

All rights reserved. No reuse allowed without permission.

Reserved space. Do not place any text in this section. Include the mandatory author checklist or your manuscript will be returned. Use continuous line numbering in your manuscript.

Article Summary Line: The BNT162b2 vaccine was found to be less effective in protecting against

Covid-19 infection after six months, and vaccination with a third dose is indicated.

Running Title: BNT162b2 vaccine effectiveness after six months

Keywords: COVID-19, serologic tests, vaccines, epidemiology, public health, infections, immune

response

Title: Effectiveness of the mRNA BNT162b2 vaccine six months after vaccination: findings from a large

Israeli HMO

Authors: Jennifer Kertes, Sharon Baruch Gez, Yaki Saciuk, Lia Supino-Rosin, Naama Shamir Stein,

Miri Mizrahi-Reuveni, Anat Ekka Zohar

\title{
Affiliations:
}

Maccabi HealthCare Services, Israel (J. Kertes, S. Baruch Gez, Y. Saciuk, L. Supino-Rosin, N.

\section{Abstract-149 words}

Israel is currently experiencing a new wave of CoVid-19 infection, six months after implementing a

national vaccination campaign. We carried out three discrete analyses using data from a large Israeli

HMO to determine whether IgG levels of those fully vaccinated drop over time, the relationship between

IgG titer and subsequent PCR-confirmed infection, and compare PCR-confirmed infection rates by period

of vaccination. We found that mean IgG antibody levels steadily decreased over the six-month period in

the total tested population, and in all age groups. An inverse relationship was found between $\operatorname{IgG}$ titer and 
medRxiv preprint doi: https://doi.org/10.1101/2021.09.01.21262957; this version posted September 7, 2021. The copyright holder for this preprint (which was not certified by peer review) is the author/funder, who has granted medRxiv a license to display the preprint in All rights reserved. No reuse allowed without permission.

Reserved space. Do not place any text in this section. Include the mandatory author checklist or your manuscript will be returned. Use continuous line numbering in your manuscript.

vaccinated had lower initial IgG levels, and were at greater risk of infection. The findings support the

decision to add a booster vaccine for those aged 60 and over.

Text (word count: 3,223 )

\section{INTRODUCTION:}

The first case of Covid-19 was identified in Israel at the end of February 2019.(1) As in other countries,

Israel has experienced a number of infection waves. The third and largest wave to-date, largely attributed

to the entry of the Alpha variant to Israel, commenced in September 2020. At its' peak, over 8,000 new

cases were being identified daily.(2) Israel was among the first countries to introduce a national

vaccination campaign, using the mRNA BNT162b2 vaccine (Pfizer-BioNTech@). The BNT162b2

vaccine received emergency approval for use by the FDA after demonstrating 95\% efficacy over an

average two-month follow-up period.(3,4) The vaccine was initially approved for any person aged 16 and

over, with a recommended 21-day interval, two-dose administration. The vaccine campaign commenced

on the $20^{\text {th }}$ December 2020 (concurrent with a two-month nationwide lockdown), first targeting all

healthcare workers and the $60+$ population, and quickly extending to all the population aged $16+$.

Initially those members with a prior infection were not eligible for vaccination, but within three months,

policy was changed to offer a single dose to all those with prior infection. By April 2021, over 50\% of

those aged 16 and over, and $88 \%$ of the $50+$ age group country-wide had been fully vaccinated.(2)

Incidence rates dropped to 140/day by April 2021.(2) Initial population-based studies in Israel comparing

the vaccinated and unvaccinated, reported vaccine effectiveness rates of $95 \% .(5,6)$

One of the biggest questions regarding the vaccine is the length of protection provided. In publishing its 
medRxiv preprint doi: https://doi.org/10.1101/2021.09.01.21262957; this version posted September 7, 2021. The copyright holder for this preprint (which was not certified by peer review) is the author/funder, who has granted medRxiv a license to display the preprint in All rights reserved. No reuse allowed without permission.

Reserved space. Do not place any text in this section. Include the mandatory author checklist or your manuscript will be returned. Use continuous line numbering in your manuscript.

current wave are infected with the Delta variant (B.1.617.2) (unpublished data provided by Israel Ministry

of Health Laboratories). Initial serological studies of the Delta variant suggest that the BNT162b2 vaccine

provides protection against Delta-variant infection, but at lower rates than for the Alpha variant (88\% vs

93.7\% respectively).(8) Given the rise in infection rates, the dilemma arose whether this rise was

attributable to reduced effectiveness of the vaccine against the Delta variant or a waning of protection

provided by the vaccine over time.

The objective of this study was to determine if the BNT162b2 vaccine had become less effective in

preventing infection, and if so, in which population groups and to what degree. In order to meet this

objective, we carried out three discrete analyses to answer the following questions: a) do antibody levels

\section{METHODS:}

We conducted a series of retrospective cohort analyses to meet the study objectives. All data were

extracted from the Maccabi HealthCare Services database. Maccabi is the second largest HMO in Israel, 
medRxiv preprint doi: https://doi.org/10.1101/2021.09.01.21262957; this version posted September 7, 2021. The copyright holder for this preprint (which was not certified by peer review) is the author/funder, who has granted medRxiv a license to display the preprint in All rights reserved. No reuse allowed without permission.

Reserved space. Do not place any text in this section. Include the mandatory author checklist or your manuscript will be returned. Use continuous line numbering in your manuscript.

out among specific target populations (such as employees (19\%) and residents and employees of geriatric

medical and retirement home facilities owned by the HMO (4\%)) at discrete points in time, but the

majority of testing was carried out in the general HMO population (77\%) for whom testing is freely

available upon request. IgG antibody testing was carried out using SARS-CoV-2 specific anti-spike

antibodies with follow-up chemo-luminescence immunoassay (Quant II IgG anti-Spike CoV2-SARS by

Abbott (Illinois, USA)) and reported as AU/ml (Arbitrary units). Antibody levels are reported

numerically, except for outliers (below 21 and above 40,000 AU/ml) which are coded. Coded results were

converted to numeric results ('below 21' as 21 and 'above 40,000' as 40,001).

IgG antibody levels of the vaccinated population over time: All HMO members that had received both

vaccine doses and had a subsequent IgG test for SARS-CoV-2 antibodies at least seven days after the

second vaccination were included in this component of the study. The study period extended from $11^{\text {th }}$

January 2021 (when those first vaccinated reached day seven post- second dose) to $7^{\text {th }} \mathrm{July} 2021 . \operatorname{IgG}$

antibody results were mapped over the 180-day period, by demographic and health characteristics (age

group, gender, socio-economic status and presence of selected chronic illnesses).

that had a PCR test (irrespective of vaccination status) between $1^{\text {st }}$ June 2021 and $14^{\text {th }}$ July 2021 (peak of

fourth wave of infection to date) with an IgG serology test between seven and 120 days prior to the PCR

test were included in this component of the study. Last test result was included for those with more than

one test. Last PCR test date was utilized if all results were negative and first positive PCR test date was

utilized for those more than one result. The proportion of participants with subsequent positive PCR

results by antibody level status was calculated.

Comparison of infection rates by vaccination period: All HMO members who, as of the 9.6.2021, were

at least seven days post- second vaccination dose with no prior positive PCR result were included in this

component of the study. Members having received three doses or with an appointment to receive the third 
medRxiv preprint doi: https://doi.org/10.1101/2021.09.01.21262957; this version posted September 7, 2021. The copyright holder for this preprint (which was not certified by peer review) is the author/funder, who has granted medRxiv a license to display the preprint in All rights reserved. No reuse allowed without permission.

Reserved space. Do not place any text in this section. Include the mandatory author checklist or your manuscript will be returned. Use continuous line numbering in your manuscript.

population was categorized by vaccination completion: Jan-Feb 2021 and Mar-May 2021. For both

groups, the proportion that were tested PCR-positive between 9.6.2021-18.7.2021 (yes/no) was

calculated.

Statistical Analyses: Mann Whitney and Kruskal Wallis tests were carried out to compare antibody

levels over time between different population groups. Linear regression was used to identify those factors

associated with serology level. Ln of serology levels evidenced a normal distribution and was selected as

the outcome variable. Other variables entered into a hierarchical model were a) days from vaccination, b)

age, gender and socio-economic status, and c) selected chronic illnesses.

Chi square analyses were used to test the association between serology levels (categorized) with PCR

Kaplan-Meier survival curves were calculated to compare time from serologic test to positive PCR result

for the serology categories using log-rank tests. Event was defined as positive PCR result. Time to event

\section{RESULTS:}

\section{IgG antibody levels of the vaccinated population over time $(N=8,395)$ :}

The description of the study population is provided in Table 1. Of all HMO members who received both

not IgG tested.

Serology levels in the study population were found to decrease over time from a mean of 14,008 for 
medRxiv preprint doi: https://doi.org/10.1101/2021.09.01.21262957; this version posted September 7, 2021. The copyright holder for this preprint (which was not certified by peer review) is the author/funder, who has granted medRxiv a license to display the preprint in All rights reserved. No reuse allowed without permission.

Reserved space. Do not place any text in this section. Include the mandatory author checklist or your manuscript will be returned. Use continuous line numbering in your manuscript.

results were stratified by age group, gender, socio-economic status and selected chronic illnesses (Table

2). The largest mean differences between sub-populations were observed in their initial serology levels

(within the first month). Serology levels of participants aged 60 and over were almost half those of

participants under the age of 60 in the first month, attenuating to a less than $10 \%$ difference six months

later (Figure 1). Large differences in initial serology levels were also observed for participants with

chronic illness, in particular participants with immunosuppressive disorder, CKD or heart disease. Initial

(first-month) serology levels increased by socio-economic level.

Of all those that were vaccinated with both doses, $2.8 \%$ also had a positive PCR result. Comparable

serology level for those tested in the first 7-30 days was much higher than for the total study population

$(22,630 \mathrm{AU} / \mathrm{ml}, \mathrm{p}<.001)$.

When demographic and health variables were entered into a linear regression model (Appendix, Table

\section{Relationship between IgG antibody levels and subsequent SARS-CoV-2 Infection (N=5,141):}

Demographic and health characteristics of HMO members with a serology result who had subsequently

Of all those who had both tests $(\mathrm{N}=5,141), 57 \%$ had a serology test result of $150 \mathrm{AU} / \mathrm{ml}$ and lower, $6 \%$

had a result between 150-299 AU/ml, 10\% had a test result between 300-799 AU/ml and 27\% had a result 
medRxiv preprint doi: https://doi.org/10.1101/2021.09.01.21262957; this version posted September 7, 2021. The copyright holder for this preprint (which was not certified by peer review) is the author/funder, who has granted medRxiv a license to display the preprint in All rights reserved. No reuse allowed without permission.

Reserved space. Do not place any text in this section. Include the mandatory author checklist or your manuscript will be returned. Use continuous line numbering in your manuscript.

serology levels for the 42 study participants with a positive PCR result was 175 (SD: 490) compared to a

mean serology level of 2057 (SD: 6030) for those with a negative result ( $p<.001)$.

Of all the study participants for this component of the study, $365(7 \%)$ had a prior infection (37\% of

Figure 2. The curves indicate that participants with lower serology level $(</=300 \mathrm{AU} / \mathrm{ml})$ had lower

At the time of the study, $86 \%$ of those eligible for vaccination (aged 16+) had received both doses in the

Factors associated with subsequent infection (positive PCR result) in a logistic regression model (Table

5) were socio-economic status, age group, vaccination period, gender and heart disease. When controlling

\section{DISCUSSION:}

In this study, we established that IgG serology levels for SARS-CoV-2 virus decreased progressively 
medRxiv preprint doi: https://doi.org/10.1101/2021.09.01.21262957; this version posted September 7, 2021. The copyright holder for this preprint (which was not certified by peer review) is the author/funder, who has granted medRxiv a license to display the preprint in perpetuity.

Reserved space. Do not place any text in this section. Include the mandatory author checklist or your manuscript will be returned. Use continuous line numbering in your manuscript.

demographic and health variables. We also established a clear association between serology levels and

subsequent risk of infection, wherein participants with a serology level of $300 \mathrm{AU} / \mathrm{ml}$ or lower were more

likely to get infected with CoVid-19 than those with a serology level above 300 AU/ml. Finally, we

established that those vaccinated at the beginning of the national vaccination campaign were more likely

to get infected (during the current wave of infection) than those vaccinated later. These findings suggest

that effectiveness of the vaccine does drop over time and that the current wave of infection can be

attributed, at least in part, to the vaccine's reduced effectiveness over time.

IgG antibody levels of the vaccinated population over time:

Initial serological studies focused on patients found PCR positive for CoVid-19, and reported a decrease over time of antibody presence from time of infection.(9-11) Fewer studies have looked specifically at serological response of the vaccinated population. Most of the studies based on vaccinated populations much higher amongst the vaccinated population than those convalescing after infection(12) and those under the age of 50.(13) In a case-control study of PCR positive cases divided by prior vaccination status (yes/no), Lopez-Bernal et al. (2021)(8) found that those vaccinated (two dose) with the BNT162b2 vaccine with the Alpha variant achieved $93.7 \%$ vaccine effectiveness, compared to an $88 \%$ vaccine effectiveness rate for those infected with the Delta variant.

We did not find studies published describing serological status over longer follow-up periods for a vaccinated population. Mean levels of IgG antibody decreased progressively over time for all subpopulations in this study. The difference between the groups was mostly evident in initial (first month) starting means, with the elderly and those suffering from chronic illness having lower levels, but household study, IgG response was measured over the first three months(14) found higher seroconversion rates for younger age groups (20-40), females, those receiving both doses, vaccination with 
medRxiv preprint doi: https://doi.org/10.1101/2021.09.01.21262957; this version posted September 7, 2021. The copyright holder for this preprint (which was not certified by peer review) is the author/funder, who has granted medRxiv a license to display the preprint in perpetuity.

Reserved space. Do not place any text in this section. Include the mandatory author checklist or your manuscript will be returned. Use continuous line numbering in your manuscript.

Low responders were older and had higher prevalence of chronic illness/disease, such as patients on

immune-suppressants or suffering from diabetes. These same population groups, were found in this study

to start with lower serology levels and have lower mean serology levels six-months post- vaccination.

Relationship between IgG antibody levels and subsequent SARS-CoV-2 Infection:

One of the many unknowns regarding CoVid-19 is to what extent IgG antibody presence is indicative of

protection against the virus. The manufacturer's recommended cut-off indicating a positive serological

response $(<50 \mathrm{AU} / \mathrm{ml})$ is much lower than the mean serology levels found in the sixth month post-

vaccination in the present study. Are higher levels indicative of higher protection? Other mechanisms of

protection, such as anti-viral $\mathrm{T}$ and $\mathrm{B}$ cell memory have been suggested as offering protection, even in the

absence of seroconversion.(15) Khoury et al (2021)(16), in a meta-analysis, found a strong relationship

between mean neutralization levels and reported protection. They further estimated that protection was

likely to fall over 250 days, although with still largely preserved protection from severe infection. In the

Comparison of infection rates by vaccination period:

Little data is available to compare vaccine effectiveness over time, with observational follow-up studies

becoming less appropriate, given the potential bias between those electing to vaccinate and those that do 
medRxiv preprint doi: https://doi.org/10.1101/2021.09.01.21262957; this version posted September 7, 2021. The copyright holder for this preprint (which was not certified by peer review) is the author/funder, who has granted medRxiv a license to display the preprint in All rights reserved. No reuse allowed without permission.

Reserved space. Do not place any text in this section. Include the mandatory author checklist or your manuscript will be returned. Use continuous line numbering in your manuscript.

when the individual was vaccinated. We suggest that the difference found here between time periods

indicates a reduction in vaccine effectiveness over time. We cannot rule out, however, some contribution

of the Delta variant to reduced effectiveness.

The study findings here are subject to a number of limitations. Firstly, serology test findings were not

based on repeated tests in the same population, but a description of the results over time of a non-

randomly selected population. Those presenting for serology and PCR testing were not a randomly

selected group. Mean serology levels were calculated for each sub-population, despite the potential for

outlier measures to skew results, to allow statistical comparison between sub-population groups. Numbers

caution. Study findings were not adjusted for serology test accuracy. Conclusions are made on the

assumption that the majority of those infected in the third component of the study (by time of

vaccination) were infected with the Delta variant, given its' prevalence in Israel.

Given these limitations, the different elements of the study were based on large numbers of a vaccinated and morbidity rates in this group will allow us to confirm the wisdom of providing a booster dose.

Disclaimers The opinions expressed by authors contributing to this journal do not necessarily reflect the 
medRxiv preprint doi: https://doi.org/10.1101/2021.09.01.21262957; this version posted September 7, 2021. The copyright holder for this preprint (which was not certified by peer review) is the author/funder, who has granted medRxiv a license to display the preprint in All rights reserved. No reuse allowed without permission.

Reserved space. Do not place any text in this section. Include the mandatory author checklist or your manuscript will be returned. Use continuous line numbering in your manuscript.

Author Bio Jennifer Kertes MPH, is a senior researcher in the Division of data \& digital health, Maccabi

Healthcare Services and has been involved in the design and implementation (data extraction, analysis

and interpretation and summary) of innumerable epidemiological and public health studies for the HMO

for over twenty years. Her primary research interests include public health and health promotion studies

(especially regarding smoking) and pharma-therapeutic studies.

References:

1. Rosen B, Waitzberg R, Israeli A. Israel's rapid rollout of vaccinations for COVID-19. Isr J Health

Policy Res. 2021;10(1):1-14.

2. Leshem E, Wilder-Smith A. COVID-19 vaccine impact in Israel and a way out of the pandemic.

Lancet. 2021;397(10287):1783-1785.

3. Vaccines and Related Biological Products Advisory Committee Meeting, Dec $10^{\text {th }} 2020$. FDA

Briefing Document - Pfizer BioNTech COVID-19 vaccine. 2021.

4. Polack FP, Thomas SJ, Kitchin N, Absalon J, Gurtman A, Lockhart S, et al. Safety and efficacy of

5. Haas EJ, Angulo FJ, McLaughlin JM, Anis E, Singer SR, Khan F, et al. Impact and effectiveness of mRNA BNT162b2 vaccine against SARS-CoV-2 infections and COVID-19 cases, hospitalisations, and dealth following a nationwide vaccination campaign in Israel: an observational study using national surveillance data. Lancet. 2021;397(10287):1819-1829.

6. Dagan N, Barda N, Kepten E, Miron E, Perchik S, Katz MA, et al. BNT162b2 mRNA COVID-19 vaccine in a nationwide mass vaccination setting. N Engl J Med. 2020;384(15):1412-1423.

7. Thomas SJ, Moreira ED, Kitchin N, Absalon J, Gurtman A, Lockhart S, et al. Six month safety and efficacy of the BNT162b2 mRNA COVID-19 vaccine. medRxiv [Preprint] [Cited July 28, 2021]. 
medRxiv preprint doi: https://doi.org/10.1101/2021.09.01.21262957; this version posted September 7, 2021. The copyright holder for this preprint (which was not certified by peer review) is the author/funder, who has granted medRxiv a license to display the preprint in All rights reserved. No reuse allowed without permission.

Reserved space. Do not place any text in this section. Include the mandatory author checklist or your manuscript will be returned. Use continuous line numbering in your manuscript.

8. Lopez Bernal J, Andrews N, Gower C, Gallagher E, Simmons R, Thelwall S, et al. Effectiveness of

Covid-19 vaccines against the B.1.617.2 (Delta) Variant. N Engl J Med. Aug 12;385(7):585-594.

Epub 2021 Jul 21.

9. Zhao J, Yuan Q, Wang H, Liu W, Liao X, Su Y, et al. Antibody responses to SARS-CoV-2 in

patients of novel coronavirus disease 2019. Clin Infect Dis. 2020;71(16):2027-2034.

10. Zhou W, Xu X, Chang Z, Wang H, Zhong X, Tong X, et al. The dynamic changes of serum IgM and IgG against SARS-CoV-2 in patients with COVID-19. J Med Virol. 2021;93(2):924-933.

11. Harvey RA, Rassen JA, Kabelac CA, Turenne W, Leonard S, Klesh R, et al. Association of

SARS-CoV-2 seropositive antibody test with risk of future infection. JAMA Intern Med.

286

2021;181(5):672-679.

12. Jalkanen P,, Kolehmainen P, Häkkinen HK, Huttunen M, Tähtinen PA, Lundberg R, et al.

COVID-19 mRNA vaccine induced antibody responses against three SARS-CoV-2 variants. Nat

Commun. 2021;12(1):3991.

13. Grupel D, Gazit S, Schreiber L, Nadler V, Wolf T, Lazar R, et al. Kinetics of SARS-CoV-2 anti-S

IgG after BNT162b2 vaccination. Vaccine. Aug 11;S0264-410X(21)01045-8. Epub PMID:

14. Wei J, Stoesser N, Matthews PC, Ayoubkhani D, Studley R, Bell I, et al. Antibody responses to

SARS-CoV-2 vaccines in 45,965 adults from the general population of the United Kingdom. Nat

Microbiol. July 2021:1-10. Epub. PMID: 34290390

15. Cox RJ, Brokstad KA. Not just antibodies: B cells and Tcells mediate immunity to COVID-19.

Nat Rev Immunol. 2020;20(10):581-582.

16. Khoury DS, Cromer D, Reynaldi A, Schlub TE, Wheatley AK, Juno JA et al. Neutralizing

antibody levels are highly predictive of immune protection from symptomatic SARS-CoV-2

infection. Nat Med. 2021;27(7):1205-1211. 
medRxiv preprint doi: https://doi.org/10.1101/2021.09.01.21262957; this version posted September 7, 2021. The copyright holder for this preprint (which was not certified by peer review) is the author/funder, who has granted medRxiv a license to display the preprint in perpetuity.

All rights reserved. No reuse allowed without permission.

Reserved space. Do not place any text in this section. Include the mandatory author checklist or your manuscript will be returned. Use continuous line numbering in your manuscript.

Table 1: Demographic and Health Characteristics of vaccinated population by serology test status, Jan-

Jun 2021, Maccabi HealthCare Services, Israel

\begin{tabular}{|c|c|c|c|}
\hline Characteristic & Category & $\begin{array}{l}\text { No. (\%) Not Tested } \\
\mathrm{N}=1,423,257\end{array}$ & $\begin{array}{l}\text { No. (\%) Tested } \\
\mathrm{N}=8,395\end{array}$ \\
\hline \multirow[t]{2}{*}{ Gender } & Males & $683,946(48.1)$ & $2,774(33.0)$ \\
\hline & Females & $739,311(51.9)$ & $5,621(67.0)$ \\
\hline \multirow[t]{5}{*}{ Age Group } & $<18$ & $39,123(2.7)$ & $92(1.1)$ \\
\hline & $18-44$ & $644,038(45.3)$ & $2,199(26.2)$ \\
\hline & $45-59$ & $384,100(27.0)$ & $3,016(35.9)$ \\
\hline & $60-74$ & 255,377 (17.9) & $2,515(30.0)$ \\
\hline & $75+$ & $100,619(7.1)$ & $573(6.8)$ \\
\hline \multirow[t]{3}{*}{ Socioeconomic bracket } & Low & $481,470(33.8)$ & $3,202(38.1)$ \\
\hline & Middle & $232,824(16.4)$ & $1,281(15.3)$ \\
\hline & High & 708,963 (49.8) & $3,912(46.6)$ \\
\hline \multirow[t]{2}{*}{ Heart Disease } & No & $1,346,990(94.6)$ & $7,790(92.8)$ \\
\hline & Yes & $76,267(5.4)$ & 605 (7.2) \\
\hline \multirow[t]{2}{*}{ Diabetes } & No & $1,297,140(91.1)$ & $7,342(87.5)$ \\
\hline & Yes & $126,117(8.9)$ & $1,053(12.5)$ \\
\hline \multirow[t]{2}{*}{ Hypertension } & No & $1,145,327(80.5)$ & $5,960(71.0)$ \\
\hline & Yes & $277,930(19.5)$ & $2,435(29.0)$ \\
\hline \multirow[t]{2}{*}{ CKD } & No & $1,353,406(95.1)$ & $7,715(91.9)$ \\
\hline & Yes & $69,851(4.9)$ & $680(8.1)$ \\
\hline \multirow[t]{2}{*}{ Immunosuppressive Disorder } & No & $1,396,529(98.1)$ & $7,411(88.3)$ \\
\hline & Yes & $26,728(1.9)$ & $984(11.7)$ \\
\hline
\end{tabular}

Table 2: Demographic and Health Characteristics of vaccinated population by PCR test status, June-July

\begin{tabular}{|l|l|c|c|}
\hline Characteristic & Category & $\begin{array}{l}\text { No. (\%) Not Tested } \\
\mathbf{N = 7 9 , 4 0 4}\end{array}$ & $\begin{array}{l}\text { No. (\%) Tested } \\
\mathbf{N = 5 , 1 4 1}\end{array}$ \\
\hline Gender & Males & $33,871(42.7)$ & $2,128(41.4)$ \\
\hline Age Group & Females & $45,533(57.3)$ & $3,013(58.6)$ \\
\hline & $<18$ & $21,563(27.2)$ & $937(18.2)$ \\
\hline & $18-44$ & $37,470(47.2)$ & $2,338(45.5)$ \\
\hline & $45-59$ & $13,553(17.1)$ & $1,090(21.2)$ \\
\hline Socioeconomic bracket & $60-74$ & $5,672(7.1)$ & $657(12.8)$ \\
\hline & $75+$ & $1,146(1.4)$ & $119(2.3)$ \\
\hline Heart Disease & Low & $10,744(13.5)$ & $1,339(26.0)$ \\
\hline & Middle & $36,358(45.8)$ & $1,234(24.0)$ \\
\hline Diabetes & High & $32,302(40.7)$ & $2,568(50.0)$ \\
\hline & No & $78,105(98.4)$ & $5,021(97.7)$ \\
\hline Hypertension & Yes & $1,299(1.6)$ & $120(2.3)$ \\
\hline CKD & No & $76,320(96.1)$ & $4,903(95.4)$ \\
\hline & Yes & $3,084(3.9)$ & $238(4.6)$ \\
\hline Immunosuppressive Disorder & No & $73,063(92.0)$ & $4,524(88.0)$ \\
\hline & Yes & $6,341(8.0)$ & $617(12.0)$ \\
\hline & No & $78,058(98.3)$ & $5,012(97.5)$ \\
\hline & Yes & $1,346(1.7)$ & $129(2.5)$ \\
\hline & Yes & $78,193(98.5)$ & $5,010(97.5)$ \\
\hline & & $1,211(1.5)$ & $131(2.5)$ \\
\hline
\end{tabular}


medRxiv preprint doi: https://doi.org/10.1101/2021.09.01.21262957; this version posted September 7, 2021. The copyright holder for this preprint (which was not certified by peer review) is the author/funder, who has granted medRxiv a license to display the preprint in perpetuity.

All rights reserved. No reuse allowed without permission.

Reserved space. Do not place any text in this section. Include the mandatory author checklist or your manuscript will be returned. Use continuous line numbering in your manuscript.

Table 3: Demographic and Health Characteristics of vaccinated population by vaccination

period, Jan-May 2021, Maccabi HealthCare Services, Israel

\begin{tabular}{|l|l|c|c|}
\hline Characteristic & Category & $\begin{array}{c}\text { Jan-Feb } \\
\mathbf{N = 8 2 1 , 2 3 1}\end{array}$ & $\begin{array}{c}\text { Mar-May } \\
\mathbf{N = 6 0 1 , 8 6 7}\end{array}$ \\
\hline Gender & Males & $394,546(48.0)$ & $285,089(47.6)$ \\
\hline Age Group & Females & $426,685(52.0)$ & $313,482(52.4)$ \\
\hline & $<18$ & $21,232(2.6)$ & $62,793(10.4)$ \\
\hline & $18-44$ & $211,351(25.7)$ & $414,514(68.9)$ \\
\hline & $45-59$ & $289,813(35.3)$ & $86,013(14.3)$ \\
\hline Socioeconomic bracket & $60-74$ & $219,437(26.7)$ & $28,620(4.8)$ \\
\hline & $75+$ & $79,398(9.7)$ & $9,927(1.6)$ \\
\hline Heart Disease & Low & $102,689(12.5)$ & $125,924(20.9)$ \\
\hline & Middle & $398,474(48.5)$ & $307,724(51.1)$ \\
\hline Diabetes & High & $320,068(39.0)$ & $168,219(27.9)$ \\
\hline & No & $755,979(92.1)$ & $592,608(98.5)$ \\
\hline Hypertension & Yes & $65,252(7.9)$ & $9,259(1.5)$ \\
\hline & No & $717,950(87.4)$ & $581,893(96.7)$ \\
\hline CKD & Yes & $103,281(12.6)$ & $19,974(3.3)$ \\
\hline Immunosuppressive Disorder & No & $593,368(72.3)$ & $556,545(92.5)$ \\
\hline & Yes & $227,863(27.7)$ & $45,322(7.5)$ \\
\hline & No & $762,717(92.9)$ & $592,447(98.4)$ \\
\hline & Yes & $58,514(7.1)$ & $9,420(1.6)$ \\
\hline & Yes & $808,061(98.4)$ & $598,499(99.4)$ \\
\hline & & $13,170(1.6)$ & $3,368(0.6)$ \\
\hline
\end{tabular}

Table 4: Mean antibody level by demographic and health variables and time from vaccination (days), JanJune 2021, Maccabi HealthCare Services, Israel

\begin{tabular}{|c|c|c|c|c|c|c|c|c|}
\hline \multirow[t]{2}{*}{ Characteristic } & \multirow[t]{2}{*}{ Measure } & \multicolumn{7}{|c|}{ Days from vaccination to serology test } \\
\hline & & $7-29$ & $30-59$ & $60-89$ & $90-119$ & $120-150$ & $150+$ & p value \\
\hline \multirow{4}{*}{ Total population } & $\mathrm{N}$ & 2,457 & 1,845 & 946 & 827 & 500 & 1,820 & \\
\hline & Mean & 14,008 & 8,175 & 4,365 & 2,706 & 1,773 & 1,411 & $<.001$ \\
\hline & (SD) & $(12,146)$ & $(7,742)$ & $(5,022)$ & $(3,957)$ & $(1,934)$ & $(1,751)$ & \\
\hline & Median & 11,322 & 6,080 & 2,974 & 1,683 & 1,217 & 1,217 & \\
\hline \multicolumn{9}{|l|}{ Gender } \\
\hline \multirow[t]{2}{*}{ Males } & $\mathrm{N}$ & 1,075 & 676 & 354 & 269 & 105 & 295 & \\
\hline & Mean & 12,278 & 6,837 & 3,799 & 2,633 & 1,695 & 1,309 & $<.001$ \\
\hline \multirow[t]{2}{*}{ Females } & $\mathrm{N}$ & 1,382 & 1,169 & 592 & 558 & 395 & 1,525 & \\
\hline & Mean & 15,354 & 8,949 & 4,703 & 2,740 & 1,794 & 1,431 & \\
\hline \multicolumn{9}{|l|}{ Age group } \\
\hline \multirow[t]{2}{*}{$<60$} & $\mathrm{~N}$ & 1,453 & 1,111 & 564 & 444 & 366 & 1,369 & \\
\hline & Mean & 17,169 & 9,526 & 5,044 & 3,099 & 1,959 & 1,439 & $<.001$ \\
\hline \multirow[t]{2}{*}{$60+$} & $\mathrm{N}$ & 1,004 & 734 & 382 & 383 & 134 & 451 & \\
\hline & Mean & 9,433 & 6,130 & 3,362 & 2,249 & 1,266 & 1,327 & \\
\hline \multicolumn{9}{|l|}{ Socioeconomic Status } \\
\hline \multirow[t]{2}{*}{ Low } & $\mathrm{N}$ & 553 & 278 & 143 & 113 & 59 & 135 & \\
\hline & Mean & 15,994 & 10,048 & 4,481 & 4,056 & 2,443 & 1,625 & $<.001$ \\
\hline \multirow[t]{2}{*}{ Middle } & $\mathrm{N}$ & 1,088 & 827 & 414 & 392 & 259 & 932 & \\
\hline & Mean & 13,989 & 8,473 & 4,739 & 2,523 & 1,695 & 1,468 & $<.001$ \\
\hline \multirow[t]{2}{*}{ High } & $\mathrm{N}$ & 816 & 740 & 389 & 322 & 182 & 753 & \\
\hline & Mean & 12,687 & 7,139 & 3,924 & 2,454 & 1,667 & 1,301 & $<.001$ \\
\hline \multirow[t]{2}{*}{ Heart disease } & $\mathrm{N}$ & 206 & 165 & 79 & 75 & 25 & 55 & \\
\hline & Mean & 7,341 & 4,307 & 2,520 & 2,455 & 690 & 1,575 & $<.001$ \\
\hline \multirow[t]{2}{*}{ Diabetes } & $\mathrm{N}$ & 377 & 245 & 121 & 123 & 57 & 130 & \\
\hline & Mean & 8,624 & 6,647 & 2,742 & 2,189 & 843 & 1,401 & $<.001$ \\
\hline \multirow[t]{2}{*}{ HTN } & $\mathrm{N}$ & 803 & 572 & 274 & 290 & 133 & 363 & \\
\hline & Mean & 9,930 & 6,624 & 3,032 & 2,118 & 1,341 & 1,409 & $<.001$ \\
\hline \multirow[t]{2}{*}{ CKD } & $\mathrm{N}$ & 248 & 163 & 81 & 88 & 45 & 55 & \\
\hline & Mean & 6,756 & 4,331 & 2,614 & 2,339 & 887 & 1,910 & $<.001$ \\
\hline Immunosuppressive & $\mathrm{N}$ & 307 & 280 & 156 & 126 & 57 & 58 & \\
\hline Disorder & Mean & 6,824 & 4,371 & 2,336 & 1,500 & 1,033 & 1,813 & $<.001$ \\
\hline
\end{tabular}


Reserved space. Do not place any text in this section. Include the mandatory author checklist or your manuscript will be returned. Use continuous line numbering in your manuscript.

Table 5: Factors associated with Covid-19 infection (logistic regression model), Jan-May 2021,

Maccabi HealthCare Services, Israel

\begin{tabular}{llccc}
\hline Variable & Category & $\mathbf{N}$ & $\mathbf{O R}$ & $\mathbf{9 5 \%} \mathbf{C l}$ \\
\hline Vaccination period & Jan-Feb & 821,231 & 1.61 & $1.45-1.79$ \\
& Mar-May & 601,867 & - & \\
\hline Gender & Males & 681,382 & 0.11 & $1.01-1.20$ \\
& Females & 741,716 & - & \\
\hline Age Group & $<18$ & 84,025 & - & \\
& $18-44$ & 625,865 & 1.92 & $1.51-2.49$ \\
& $45-59$ & 375,826 & 1.88 & $1.46-2.45$ \\
& $60-74$ & 248,057 & 1.54 & $1.17-2.04$ \\
& $75+$ & 89,325 & 1.06 & $0.75-1.50$ \\
\hline Socioeconomic & Low & 228,613 & - & \\
& Moderate & 706,198 & 2.85 & $2.34-3.50$ \\
& High & 488,287 & 4.40 & $3.61-5.41$ \\
\hline Heart Disease & No & $1,348,587$ & - & \\
& Yes & 74,511 & 1.35 & $1.11-1.79$ \\
\hline Diabetes & No & $1,299,843$ & - & \\
& Yes & 123,255 & 1.03 & $0.87-1.12$ \\
\hline Hypertension & No & $1,149,913$ & - & \\
& Yes & 273,185 & 0.98 & $0.86-1.22$ \\
\hline CKD & No & $1,355,164$ & - & \\
& Yes & 67,934 & 0.82 & $0.63-1.05$ \\
\hline Immunosuppressive & No & $1,406,596$ & - & \\
Disorder & Yes & 16,502 & 0.90 & $0.58-1.63$ \\
\hline & & & & \\
\hline
\end{tabular}

Figure 1: Serology levels of vaccinated population over time by age group, Jan-June 2021, Maccabi HealthCare Services, Israel
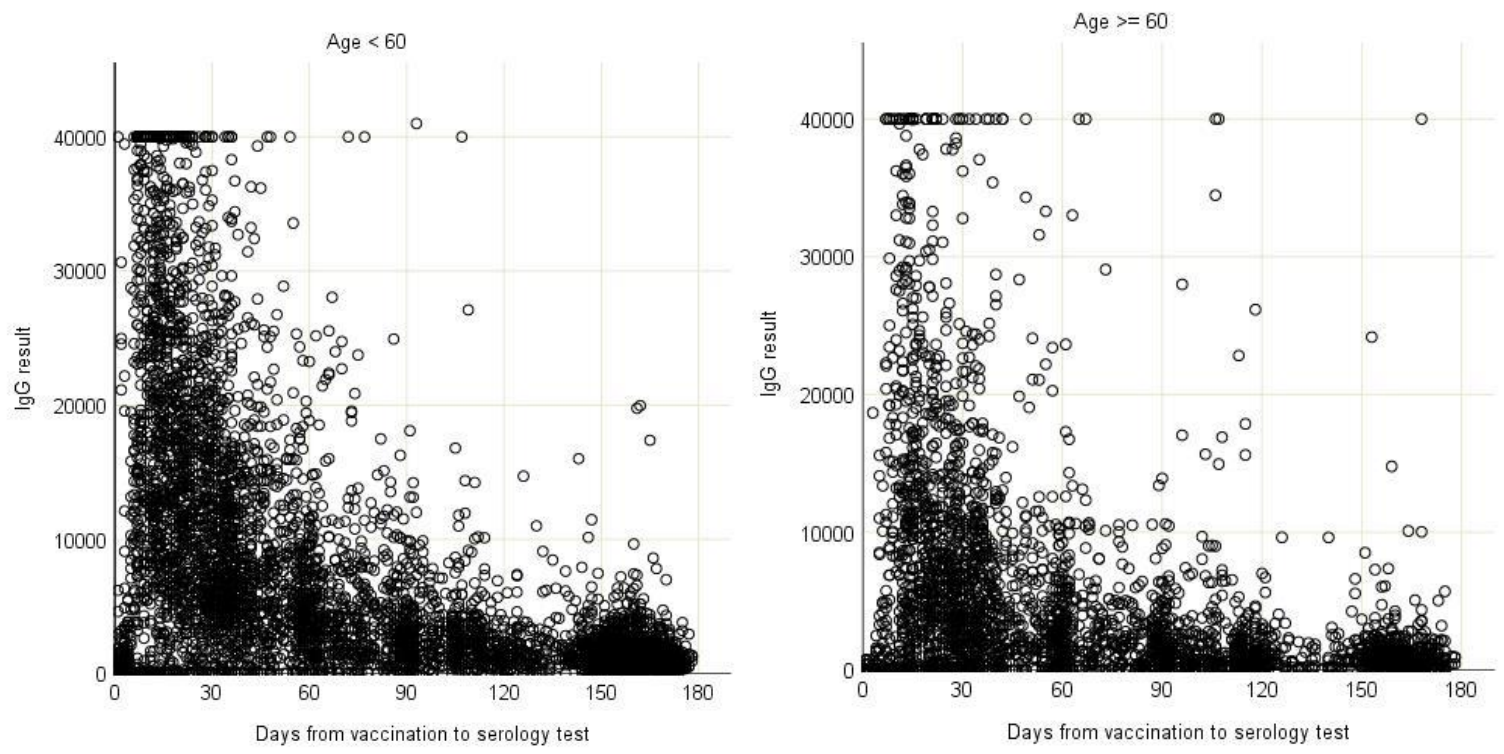
Reserved space. Do not place any text in this section. Include the mandatory author checklist or your manuscript will be returned. Use continuous line numbering in your manuscript.

Figure 2: Kaplan-Meier cumulative survival for PCR positive outcome, June-July 2021, Maccabi HealthCare Services, Israel

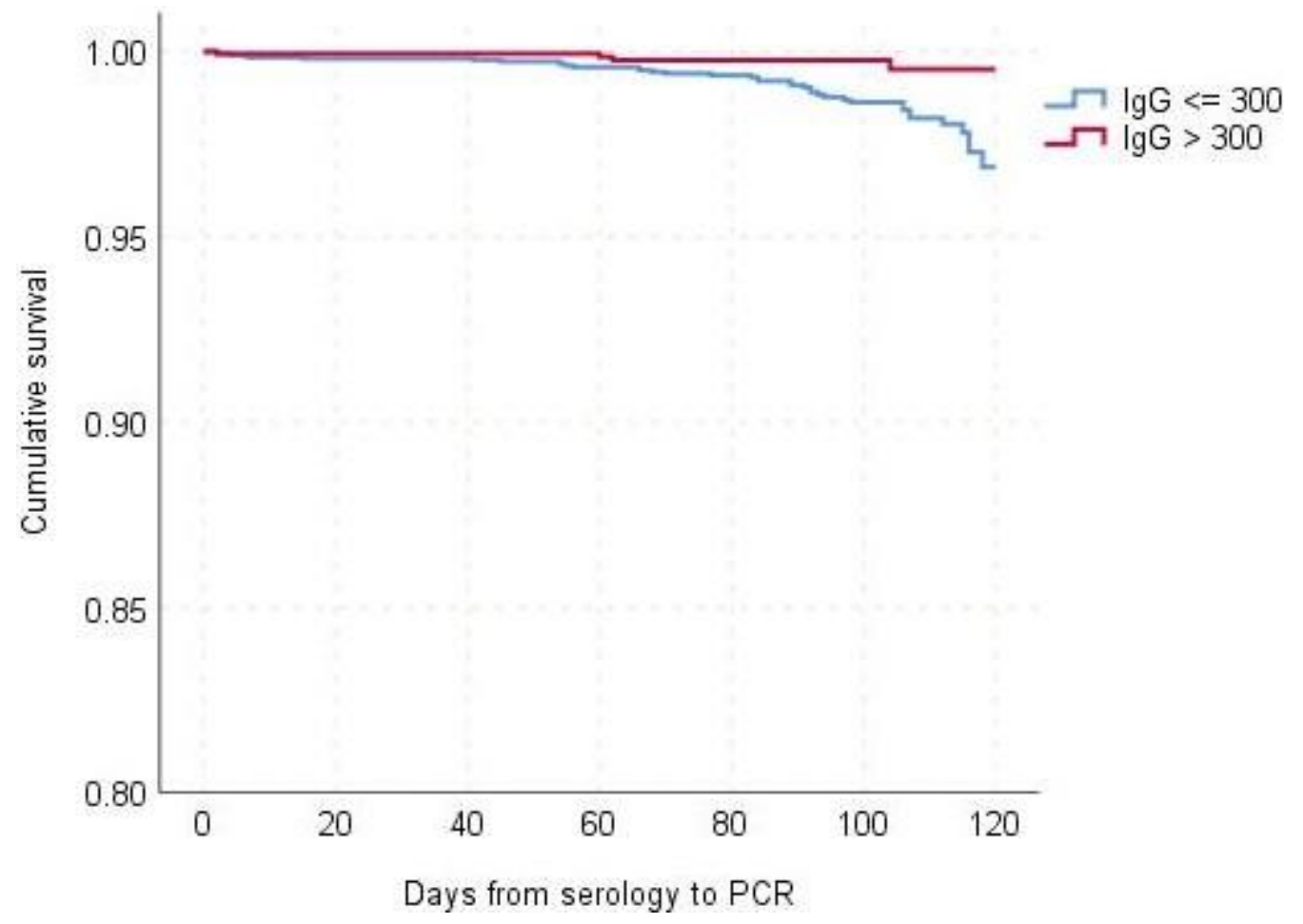

\section{Appendix}

Table A1: Factors associated with ln of serology titers (linear regression model)

\begin{tabular}{|l|c|c|}
\hline Factor & $\boldsymbol{\beta}$ & $\mathbf{p}$ value \\
\hline Days from vaccination & -.016 & $<.0001$ \\
\hline Gender (males) & -.347 & $<.0001$ \\
\hline Age (years) & -.022 & $<.0001$ \\
\hline Socio-economic status (middle) & -.078 & .033 \\
\hline Socio-economic status (high) & -.184 & $<.0001$ \\
\hline Heart Disease & -.242 & $<.0001$ \\
\hline Diabetes & -.108 & .007 \\
\hline HTN & -.105 & .001 \\
\hline CKD & -.318 & $<.0001$ \\
\hline Immunosuppressive disorder & -.888 & $<.0001$ \\
\hline
\end{tabular}

$\mathrm{R}^{2}=.498$. Dependent variable: $\ln$ of serology titer. Independent variables entered in hierarchical model: days from vaccination; gender, age and socio-economic status; chronic illnesses. 
Reserved space. Do not place any text in this section. Include the mandatory author checklist or your manuscript will be returned. Use continuous line numbering in your manuscript.

Table A2: Factors associated with a positive PCR result (univariate analysis)

\begin{tabular}{|c|c|c|c|}
\hline Factor & $\mathbf{N}$ & No. positive (\%) & p value ${ }^{\star}$ \\
\hline Gender & & & $<.01$ \\
\hline Male & 681,382 & $1,096(0.16)$ & \\
\hline Female & 741,716 & $1,066(0.14)$ & \\
\hline Age Group & & & $<.01$ \\
\hline$<18$ & 84,025 & $67(0.08)$ & \\
\hline $18-44$ & 625,865 & $916(0.15)$ & \\
\hline $45-59$ & 375,826 & $697(0.19)$ & \\
\hline $60-74$ & 248,057 & $387(0.16)$ & \\
\hline $75+$ & 89,325 & $95(0.11)$ & \\
\hline Socioeconomic & & & $<.01$ \\
\hline Low & 228,613 & $106(0.05)$ & \\
\hline Middle & 706,198 & $976(0.14)$ & \\
\hline High & 488,287 & $106(0.05)$ & \\
\hline Heart Disease & & & .03 \\
\hline No & $1,348,587$ & $2,026(0.15)$ & \\
\hline Yes & 74,511 & $136(0.18)$ & \\
\hline Diabetes & & & .47 \\
\hline No & $1,299,843$ & $1,982(0.15)$ & \\
\hline Yes & 123,255 & $177(0.14)$ & \\
\hline Hypertension & & & .22 \\
\hline No & $1,149,913$ & $1,770(0.15)$ & \\
\hline Yes & 273,185 & $392(0.14)$ & \\
\hline CKD & & & .01 \\
\hline No & $1,355,164$ & $2,083(0.15)$ & \\
\hline Yes & 67,934 & $79(0.12)$ & \\
\hline Immunosuppressive Disorder & & & .76 \\
\hline No & $1,406,560$ & $2,139(0.15)$ & \\
\hline Yes & 16,538 & $23(0.14)$ & \\
\hline
\end{tabular}

* Chi square/Fisher exact test statistic 